\title{
Reflection on 50 Years of Geography in Nigeria
}

\author{
Michael O. Filani \\ Department of Geography, University of lbadan, Nigeria
}

In 1978, the Nigeria Geographical Association published a special volume of its journal to commemorate that year's Regional Conference of the International Geographical Union (IGU). Up to that time, and to some extent today, the volume contained the most comprehensive account of Nigerian geography. The volume has four major articles, namely:

Thirty years of Geographic thought in Nigeria by G. A. Afolabi Ojo.

The Growth and contributions of the Nigerian

Geographical Association by Babafemi Ogundana Geography in Nigerian

Universities by Nurudeen Alao, and

Growth and Trend of Geographic Research in Nigeria by P.O. Sada.

Since then other publications have dealt with various aspects of the growth and development of geography as an academic discipline in Nigeria. Foremost among these are the Geographical Perspectives on Nigeria's Development (Faniran and Ayeni 1990) for the Nigerian Geographical Association. This book of readings contains speeches of the presidents of the Association from its inception in 1957 to 1970. These speeches show the concern of the doyen of Nigerian Geography "with such issues as the nature of the subject, its relevance to the identification of societal problems, and concern for the utilization of the subject by policy makers and by government (Ayeni and Faniran 1990). Other works include Geography in Nigeria (Salau 1986) and Research Trends in Nigerian Human Geography (Okafor 1989) both of which appeared in different issues of The Professional Geographer. Also, Onokerhoraye (1984) wrote on An Introduction to the History of Geographic Thought and Ojo's (1980) Geography Today, its Purpose, Content and Methods and Faniran and Okunrotifa eds. A Handbook of Geography Teaching for Schools and Colleges. 
The most recent publication whose contents are germane to the topic of this paper is 50 years of Geography in Nigeria. The Ibadan Story, edited by Areola and Okafor in 1998. The book which contains "essays by former students and past and present members of the Department is written to commemorate the golden jubilee of the Department as well as the University of Ibadan". As the editors further stated the "book is essentially about the history of academic geography in Nigeria as well as the history of the department that nurtured the discipline, especially in its formative years" (p.456).

The various sources quoted above contain a compendium of facts on the development of geography as an academic discipline in Nigeria. This paper, therefore, draws heavily on these sources. It represents more or less a synthesis, of and a commentary on the contents of the sources with particular reference to the growth and development of geographic education in Nigeria. The paper focuses on the last fifty years of Geography in Nigeria with reference to its nature and content, philosophy and methodology and the ways in which "teaching and research orientations have changed over time and the paradigm shifts ... that have engendered this dynamism" (Areola \& Okafor 1998).

\section{The Beginnings: 1948-1960}

Geography as an academic discipline started in Nigeria in 1948 when the University College, Ibadan was established and geography was one of its foundation disciplines. However, prior to this time geographic education had flourished at primary and secondary schools and Teacher Training Colleges. Geographic knowledge had also been popularized through the textbooks o some British geographers such as L.D. Stamp and J.H. Sturbridge (Ojo 1978; Okafor 1989). Earlier works also include those c Talbot (1902), Falconer (1911), and Hamilton and Archabbot (1945). As Barbour (1973) commented, these publications were scholarly studies "but not the products of academic teachers engage 
ed in professional research in the light of up-to-date developments in their subjects". Ojo (1978) also observed that "the totality of the pre-1948 activities in geography relating to Nigeria, whether from inside or outside amounted to little or nothing more than a prelude to geographic thought in Nigeria".

The period 1948-1960 coincides perfectly with what has been described as the "Ibadan era of Geography" when the Department of Geography at the University College Ibadan was the "sole performer on the stage". Nigerian geography was then dominated by expatriate influence both in terms of personnel and philosophy. In fact, until 1958 when the first Nigerian (A. L. Mabogunje), himself a product of the second generation of students in the department, was appointed assistant lecturer, the teaching staff were expatriates and mainly British. Consequently, the structure and content of the courses were essentially of the University of London type. The then "British geography's regional and descriptive approaches profoundly influenced the content of Nigerian geography" (Okafor 1989). The region was then regarded as the main focus of geography and the map its most important tool (Alao 1978). The honours degree was intensive, allowing for specialization in one of the broad thematic options. The dominant philosophy was ideographic as aptly demonstrated by Gamier in his 1957 presidential address. Gamier described geography as "a subject which aims at understanding the differential character of the earth's surface. Put more simply, it tries to find out what places are like." Considering the fact that Gamier was professor and head of Department of Geography at Ibadan and at the same time the President of the Nigerian Geographical Association when he made this pronouncement, his views dominated the scope of geography during its first phase of existence in Nigeria. According to Alao (1978) nowhere was the ideographic philosophy more apparent than in the final year original essays, which every honours undergraduate had to undertake. The essays were usually an exercise in empirical data collection in the field, followed by some 
descriptive analysis. This type of training, as noted by Alao (1978), provided "an opportunity for learning report writing" but it was defective as an intellectual exercise in specific problem solution and "as a means of enriching professional training". He further opined that the undergraduate teaching programme was designed for a society in which the urgent need was to produce graduate teachers for secondary schools and administrators for the civil service.

In terms of publications, there was scarcely any local outlet for research findings in geography at this time. The department of geography at Ibadan then "established an in-house publication called Research Notes which provided the outlet for initial ideas about a topic, or preliminary results of a study" (Mabogunje 1998). These research notes existed until about 1956 when the Nigerian Geographical Association (NGA) based also at the University College, Ibadan, was formally inaugurated and published the first volume and first number of its journal, the Nigerian Geographical Journal (NGJ). This journal has remained the only journal published by the NGA and the major outlet for reporting on research findings by local researchers. The journal carries writings on virtually every branch of the discipline and has, over the years, attracted wide readership from many other academic disciplines particularly those in the social sciences.

\section{The Period of Indigenisation and Diffusion: 1960 -1970}

Between 1960 and 1970 in Nigeria, certain significant events occurred which had profound effects on the development of geography as an academic. Nigeria became politically independent in 1960 and this gave rise to a chain of events resulting in radical changes in other spheres of life including higher education. For instance, the University College, Ibadan which, had been affiliated from its inception with the University of London became autonomous. This event had important implications for the development of an indigenous geography curriculum. In the early 
1960's also, four new universities were established at Ife, Lagos, Ahmadu.Bello (Zaria), and Nsukka. The diffusion of geography then took place with the creation of new departments in these universities, thus breaking the monopoly of Ibadan. This period also witnessed the promotion of Nigerianization of staff in the various universities. At Ibadan the number of staff of Nigerian origin continued to increase and had, by 1970, constituted the majority in the department (Mabogunje 1988). By 1968, in the other universities not only had Nigerians taken over the Chair of the departments of geography except one (Ahmadu Bello -University) majority of their staff were Nigerians. Also in the Nigerian Geographical Association, Dr. Ojo of the then University of Ife was elected in 1963 as the first Nigerian President.

In terms of geographic philosophy and methodology certain changes occurred during the period, (1960 -•1970). By 1962, Kenneth Michael Barbour assumed position as Head of Department at Ibadan. By mid-1960's, he largely echoed Garnier's views with only slight modifications. Barbour (1966) still put regional description at the core of geography. He asserted:

The geographer has been defined as one who attempts to answer three questions concerning any phenomenon that he wishes to study, namely what? where?, and why? He defines his subject matter, he describes where it is to be found and he attempts an explanation of how this has come about" The three questions that he posses are interrelated and the most important of them is the second", (p. 3-4)

Although Barbour was as concerned as Gamier, his predecessor, about what places are like, he placed additional emphasis on location. He stated:

I think all geographers would agree that without location of the objects studied, a truly geographical approach to any problem couldn't be said to have begun.

New initiatives in the methodology of geography and its curriculum in Nigeria became noticeable only in 1964 when a 
course in quantitative geography was introduced in Ibadan largely through the influence of A.L. Mabogunje. Mabogunje himself had earlier been exposed "to the pace of geographical research training" during his nine-months sabbatical leave at Northwestern University, USA, which was foremost in the field of quantitative and theoretical geography at that time. At first, according to Alao (1978), the course concentrated on the application of descriptive statistics and for six subsequent years (1964-1970) the quantitative methods based on elementary descriptive and inferential statistics spread to younger universities at Ife, Lagos, Ahmadu Bello (Zaria), Nsukka and later Benin. Quantitative revolution brought tremendous changes in the university undergraduate and graduate training programmes. The influence of the quantitative revolution was particularly radical in final-year honours original essays. The essays which had hitherto been "descriptive in" style and ideographic in philosophy" (Alao 1978) became avenues in which undergraduates were expected to use quantitative techniques to test a set of simple scientific hypotheses generated from an original investigation undertaken by the student in a local area.

The new methodology subsequently began to find expression in the research and publications of postgraduate students and staff of the various universities. According to Mabogunje (1998) "this was the period of the rise of the positivist approach in geography that saw the subject as essentially a spatial science whose overriding concern was searching for empirical regularities in the human occupancy of terrestrial space" (p. 8-9). A lot of new and controversial issues and ideas emerged and became subjects of discussion at seminars and departmental colloquium. The early practitioners of quantitative geography started producing interesting and challenging papers whose importance was recognized both locally and internationally across disciplines. They included the works by Mabogunje (1968), Abiodun (1967), Hay and Smith (1967), and Ojo (1970). 
As in other parts of the world, there was some local opposition to the introduction of quantification into geography in Nigeria. Barry Floyd (1967) condemned those he called "the mathematisers of the subject". He emphatically objected to the infusion of quantitative methods into geography in West Africa for two main reasons namely, the paucity and unreliability of data, and the need for acquisition of literary skills in any educational system (Alaol978).

The growth of interest in quantitative approach to geography sparked off a groping for a more appropriate home for geography. Geographers became increasingly aware of the close relationship between their discipline and the social sciences substantively and methodologically. Thus geography was drawn "more and more away from its traditional alignments with disciplines in the faculty of arts and increasingly into new and exciting relations with subjects in the social sciences" (Mabogunje 1998). For example, in 1967, the geography department at Ibadan changed its base from the faculty of Arts to the Faculty of the Social Sciences and closed ranks with economics, sociology and political science while still retaining its membership in the Faculty of Science. All Geography graduates then started receiving the degree of Bachelor of Science in conformity with the Faculties of Science and of the Social Sciences. A substantial reorientation and a new emphasis on the social science focus for geography had accompanied the change in Faculty base. Today, in all the universities in Nigeria, except for a few such as Jos, Zaria, and Nsukka, geography is based in the Faculty of the Social Sciences. At the University of Jos, geography is located in the Faculty of Natural Sciences, at Nsukka in the Faculty of Environmental Sciences, and Zaria in the Faculty of Science.

The period 1960-1970 can thus be characterized essentially as a period of indigenisation of staff of geography departments in Nigeria, a period of diffusion of geography as an academic discipline from its only base at Ibadan to other four newly 
established Universities and more importantly a period of "important readjustment and reorganization of the traditional content of geography"(Alao 1978). It was a period when geography through quantification adopted an increasing degree of scientific method of observation and analysis, an event which, led to the growth of association of geography with other science-oriented disciplines.

\section{The Phase of Consolidation and Professionalism: 1970 - 1984}

During the 1970s, there was a vigorous reorganization of undergraduate and postgraduate courses in most Nigerian Universities. The courses reflected the new impetus in theoretical and quantitative geography. By this time, a satisfactory mastery of the new scientific geography was accomplished and it could rightly be said that the development of modern geography in Nigeria reached its consolidation phase.

Coinciding with the development of scientific geography were the new challenges of national development. The end of the thirty-month civil war in 1970 brought about the need for reconstruction and rehabilitation of war affected places, institutions and structures (Alao 1978). This need was particularly reinforced in the Second National Development Plan (1970-1974) which emphasized the rehabilitation and reconstruction activities in order to put the nation back on its development path. The situation provided enormous challenges to planning, particularly spatial planning and the need for geographers, well trained to provide the necessary skill and competence, became obvious. During the same period, the National Universities Commission encouraged all departments to initiate programmes of training with a strong, practical orientation (Mabogunje 1998). Consequently, the goal of geographical training had to be reformulated in order to teach students the skills for constructing meaningful spatial policies and analyzing spatial implications of any given policy (Alao 1978). A new emphasis on applied or professional aspects of geography 
began. The curricular in various universities provided for specialized courses in urban and regional planning, environmental resource evaluation and management and mapping techniques (Okafor 1989). A new sense of professionalism therefore emerged and geography was tacitly seen as a policy science. The need was also felt for the creation of regular planning programmes in which geography would cooperate with other social science disciplines. At the University of Ibadan, for instance, this idea found concrete expression in the establishment of the Planning Studies Programme which was meant to act as a research institute as well as a consultancy unit in various aspects of planning. A Master of Planning Sciences (MPS) degree programme was also established with specialization in Development Planning, Industrial Planning and Regional Planning. This programme was a product of a collaborative effort among the departments of geography, headed by A.L. Mabogunje and economics headed by Ojetunji Aboyade. As Mabogunje (1998) asserted, the establishment of the programme was to ensure that the macroeconomic development planners (mainly economists) and the urban and regional planners (mainly geographers) had a degree of common core training before they moved to their different disciplinary specialization.

The quest for professionalism spread through other Universities and as Sada (1982) observed: this quest had been vigorously reinforced by the oil boom which characterized the economy of Nigeria in the 1970's and the associated materialistic inclination of the students who became more interested in professional programmes than in the more purely academic discipline. Thus, departments of geography in the universities began to develop postgraduate, non-research oriented professional courses "where the distinctive principles and skills that geography imparts could be brought to bear on efforts at meeting societal needs and goals" (Areola 1998).

The development of geographic education was also further impacted upon during this period by increased proliferation of 
universities. Between 1975 and 1976, seven additional universities were established in Ilorin, Jos, Calabar, Port Harcourt, Sokoto, and Maiduguri. All of them had geography as one of their foundation disciplines, embarking from the onset on syllabuses with modern scientific scope and orientation and some degree of professionalism. In fact, in an attempt to reflect the professional inclinations of the departments and to attract students, some of them took on such designations as Department of Geography and Planning as in Jos and Regional Planning as in Benin and Calabar.

The advent of professionalism in geography had its salutary effects. It allowed the students to acquire such skills and training, which enhanced their employment opportunities in the highly competitive private sector. Thus, there was an increased number of geography graduates employed outside the classrooms, in industries, planning offices, and among private consultancy outfits. Some of those so trained also became self employed by setting up their own enterprises.

The period 1970 - 1984 could be said to constitute the phase of consolidation of the foundation stage of geography in Nigeria. It was a period when the trend of rapid development, which began during the indigenisation phase (1960-1970), was more steadily reinforced. More Nigerians were appointed as lecturers in geography in most of the universities that existed during the period. In fact, by 1978 as many as twelve indigenous lecturers had become full-fledged professors of geography (Ojo 1978). The growth in the number of indigenous lecturers was also accompanied by diversity of specialization in the geographical researches. Such specialization include in physical geography-climatology, geomorphology, biogeography and soil, conservation and resource management and water resources, and in human geography - agricultural, urban, economic, population, political, transportation, historical, rural settlement, cultural, industrial, medical, and recreational geography (Sada 1978). Research activities also intensified during this period and the publications 
emanating from them further consolidated the entry of Nigerian geography into the stream of world geography. As noted earlier, the period was also that in which "the quest for social relevance in the Nigerian economy and polity" led to professionalism in geography and a gradual enthronement of "applied" geography in various departments.

Another important event during the period of consolidation which significantly impacted on the development of Nigerian geography was the involvement of Nigerian geographers in the activities of the International Geographical Union (IGU). Prior to 1970, only three Nigerians (A.L. Mabogunje, G.J. Afolabi Ojo and R.K. Udo) had participated in the activities of the IGU through their attendance at the International Geographical Congress (IGC) which took place in New Delhi (Ojo 1978). The Nigerian National Committee on Geography had been inaugurated by 1971. This committee was employed as a leverage for securing some governmental support for attendance of some Nigerian geographers at the 22nd IGC, which took place in Montreal in 1972. In addition to those directly sponsored by the universities and other agencies, eighteen geographers from Nigeria attended. The active participation of Nigerian geographers in the activities of the IGU at this period was noteworthy. They were intimately involved in the activities of many of the Commissions and Working Groups of the IGU as full or corresponding members. A.L. Mabogunje, the foremost Nigerian geographer, was by 1978 a Chairman of one of the IGU Commissions, as well as being the organisation's first Vice-President in 1976-1980 and President (1984-84). The important and active role which Nigerian geographers played in the IGU affairs is attested to by the fact that Nigeria was the venue of the 1978 African Regional Conference of the IGU. 


\section{Post 1984 Era}

The economic crisis in Nigeria, occasioned by the decline in oil revenue, began in 1977 and was further intensified in the 1980's. It assumed acute proportions manifesting itself in the country's balance of payment problems, biting inflation, unemployment and declining productivity. The government therefore introduced austerity measures culminating in the adoption of the structural adjustment programme. The situation resulted in the cutting down of expenditures on social services in general and the education sector in particular. The immediate effect on the universities was the inadequate financial resources to maintain and improve teaching and research facilities such as laboratories, libraries and fieldwork. Despite this, the last fifteen years have witnessed further establishment of new universities. Today, there are 38 universities in Nigeria, 26 of which belong to the Federal government and 12 to state governments.

The decline in university funding over the last two decades has had negative effects on the training of students and on the research activities and the academic progress of university lecturers. For instance, in the teaching of geography, many departments in various universities find it difficult not only to add to the stock of teaching facilities but also to maintain existing ones. The considerable increase in the population of students taking courses in geography from year to year continues to compound the problems. As for the lecturers, their remuneration became hardly adequate to maintain themselves and their families. Consequently, many university lecturers have been compelled to resign, retire 01 seek greener pastures in other countries where conditions were comparably better. For those who stayed, research grants have been hard to come by and until recently attempts to get the government to improve both living and working conditions often met with indifference, forcing them to embark frequently on strike actions. The last two decades in the history of higher education in 
Nigeria have therefore, been characterized by frequent disruption of the academic programmes of universities.

With such a situation as described above, it has become difficult to advance knowledge. Thus, the developments in the subject during the consolidation stage (19701984) have been reinforced. For instance, in order to keep body and soul together, lecturers engage more in consultancy activities in order to earn extra money than engaging in 'pure' research. A significant proportion of researches in geography then became "problem-solving oriented while" geographers became increasingly involved in offering solutions to pressing national problems. Indeed many studies by undergraduates, postgraduates and professional geographers in universities lack the spatial component. As Jeje (1989), rightly commented:

By this shift from pure to applied, geography has become enmeshed in the methodologies of cognate disciplines and academic values have tended towards specialization away from the broad all-embracing approach essential to the traditional nature of the discipline).

Research in human geography became increasingly dominated by transport analysis, urban and regional planning, micro and macroeconomics, estate management, system analysis, agricultural economics, demography and sociology. In physical geography, studies were also increasingly dominated by geology, geophysics, ecology, soil science, hydrology, land management, soil chemistry, physics etc. Some geographers have even gone to the ridiculous extent of not identifying themselves as such either when filling official forms or in designing the wordings of their complimentary cards. For example, a transport geographer could become a transport analyst while a geomorphologist or a biogeographer could assume the appellation of an environmental scientist! As noted by Adejuyigbe (1985), the main disadvantage of this type of situation to geography and geographers was that when there was need to consult specialists, the decision-makers 
would always likely go to those in these cognate fields. Having drifted away into these fields by abandoning their own original discipline, geographers began to be marginalised. Although many individual geographers came to be recognized on personal basis, geographers were perceived, according to Faniran (1990) as "jack of all trades and master of none". In the same vein, in a university inaugural lecture at the university of Ibadan, a distinguished Professor of Zoology mis-understandably referred to geography as an "orisirisi" a Yoruba expression for "all sorts" or "an octopus" discipline.

We have noted earlier the emphasis in Nigerian geography in the area of scientific approach and the application of quantification. Such emphasis, which began in 1964, had been reinforced in subsequent years. Since the middle of 1980s, however, there has been serious criticism of the positivist approach in the geographic literature particularly in Britain and in the United States. According to Bennett (1985) as described by Jeje (1989), critics of the positivist approach contended that:

* It distracts researchers from the central question of social distribution.

* It creates a false sense of objectivity by attempting to remove the observer from the observed, which in turn facilitates the control and manipulation of society.

* Its use of computers, machines and techniques subsumes people under panoply of mathematics and machinery reducing them to atomistic level by eliminating considerations of social and humanistic concerns.

* It is descriptive of existing behaviour and hence supports the status quo in society especially the social distribution of wellbeing.

* It allows no consideration of values and hence the norms by which society should be organized; and 
It attempts to construct models and theories of universal generality by a mode of inductive logic moving from particular to general. (Jeje 1990).

Such challenges to the positivist approach have also occurred in Nigeria. For instance, Areola (1990) noted that although by the 1970s the positivist paradigm had been firmly entrenched in both physical and human geography at the University of Ibadan, it had had its defects and was increasingly being challenged in the 1980s. He asserted that there had been undue emphasis on statistical analyses and a corresponding neglect of the study area, that is, the geographical setting within which problems were investigated and analysed. Areola went further to state that, unlike in the past, research works had by the late 1980s become more abstract and less identifiable with 'specific geographical setting (p.61). To him this was a classic example of the sequence of the devaluation of place or region, and a major problem associated with the scientific paradigm in geography.

The positivist approach has been criticized also on the ground that it has failed to address the important issues of equity and social justice. Okafor (1989) stated that a number of Nigerian geographers have examined problems of welfare, deprivation, and inequality from spatial perspectives. Such studies include those on poverty by Sada (1987), on inequality (Ayeni 1981; Okafor 1981), multiple deprivation in cities (Oyebanji 1984 ) and on quality of life (Salau and Izeogu 1986). Okafor (1995) has been promoting humanistic and structuralist approaches to geographical research with particular emphasis on the political economy perspective on the geography of development. Other Nigerian geographers whose works have also been couched within the political economy framework include those of Gana (1985), Filani (1985) and part of Ayeni's (1981) work on inequality. Okafor (1989) has also pointed out that the radical/structural paradigm has become evident in Nigerian geography although less well established than the welfare orientation. The two issues that are particularly evident in this 
paradigm are those of autonomy and its constraints on development and access to political and economic power and its impact on the spatial distribution of resources. This radical/ structural paradigm is not yet widely reflected, if at all, in university geography curricula in Nigeria. This may be ascribed to the fact that at present, there are few adherents to this line of thought and also postgraduate students wishing to work in this area are faced with the problems of the dearth of relevant literature at the local level, since most of the existing studies have been carried out abroad.

\section{Concluding Remarks}

This paper has highlighted the major trends, issues and processes in the development of geography in Nigeria as both a discipline and a profession in the last fifty years. Evidently "Nigerian geography has come a long way in its ideas and practices to share in, and contribute to, the versatile tradition of the subject as a field of learning" (Ojo 1978). A solid foundation has been laid for the subject in the Nigerian University system, thus enabling it "to enhance and enrich the dynamic academic heritage of the subject as a discipline of intellectual, philosophical and scientific worth and relevance". While it is true that paradigm shifts have mirrored many features of the Anglo-American geography, significant changes have occurred and the trends have been toward rigorous training in methodology and problem solving curricula emphasizing "relevance to natural development and a trend towards professionalism" (Sada 1982). It can rightly be said today, that Nigerian geography has developed some distinctive features of its own through the practitioners' research works in various fields of specialization particularly, urban, agricultural, population and transportation geography, as well as climatology, geomorphology and biogeography. Also, within the last five decades, Nigerian geographers have contributed immensely to national development. They have been called upon from time to 
time, to serve the nation in areas in which their expertise is relevant. Geographers have been involved in the organization of the country's different censuses, in national surveys of resources; in urban and regional planning; in transport planning; and in resource utilization and conservation. Many geographers have also served as members or chairmen in quite a number of State and Federal Boards, commissions, institutes and authorities dealing with subjects which include economic development, boundary adjustment, education, forestry, public service and so on and so forth. Although many among the geographers might have been called upon to serve in such capacities on their own individual merits as scholars, the fact remains that they had performed in such a way as to bring credit to their academic discipline, that is, geography.

One major contentious issue in recent times, has been the rate at which geography in Nigeria appeared to have been moving into well-delineated cognate disciplines where geographers could easily be carried away by those disciplines, ideas, techniques, and perspectives, thereby loosing the core of geography, which is spatial analysis. The concern in this area has been so prominent as to constitute topics of some past presidential addresses at the annual conferences of the Nigerian Geographical Association. Such addresses include those of Jeje (1989) on "Whither Geography" and Faniran (1990) on "Concern for Geography". These authors emphasized the necessity to reassert the geographical core. Jeje in his own address advocated that geography must return to its roots and reassert the link between the physical and human aspects of the environment and thus validate the assertion that geography is a discipline in human ecology; and revive its concern with interrelationship of environmental and social concern within place, area or context.

Jeje went further to assert that within such a concern with interrelationship, "the role of quantification is to assist in the 
validation of theory and not to promote methodological core, as quantification is not the prerogative of any one discipline".

In the same vein, Faniran (1990) noted that today's geography in Nigeria is such that much of the 'geo' in geography, in an attempt to be relevant, is fast disappearing. Yet the main thing that distinguishes geography from other scientific disciplines is the geographer's concern for space and spatial relations to which the 'geo' refers.

It is plausible to contend, therefore, that the future of geography as an academic discipline in Nigeria, can continue to be bright only if the practitioners take significant cognizance of this quest to retain the 'geo' in geography. As in other countries of the world, the problem of development in Nigeria is that it must take place in space over well-defined territories. Therefore, whether one considers economic, social or political development, in the final analysis, there would be the need to organize or re-organize space. Herein lie the challenges to the future of geography in Nigeria. The geographer is the one that is well-trained for the study of places necessary for the organization of space. Fortunately, latest developments in the tools available to the discipline, most especially the introduction of geographical information system (GIS) would facilitate the tackling of such societal problems.

\section{References}

Abiodun, J.O. (1967) Urban Hierarchy in a Developing Country, Economic Geography, 43(4): $347-67$.

Adejuyigbe, O. (1990) The Issue of Relevance in Geographic Research with Reference to Nigeria, in B. Ayeni. and A. Faniran (1990), Geographical Perspectives on Nigeria's Development, Nigerian Geographical Association, 238- 256.

Alao, N. (1978) Geography in Nigerian Universities, Nigerian Geographical Journal, Vol. 21, No.1, 31 - 37. 
Areola, O. and Okafor, S. I. eds. (1998) 50 Years of Geography in Nigeria: The Ibadan Story, Ibadan: University Press, 474.

Areola, O. (1998) Postgraduate Training at Ibadan, in Areola O. and Okafor, S.I. eds. (1998) 50 Years of Geography in Nige ria: The Ibadan Story, Ibadan: University Press, 47-74.

Ayeni, B. (1981) Spatial Aspects of Urbanization and effects on the distribution of income in Nigeria, in H. Bienen and V. Diejomaoh (eds.) Inequality and Development in Nigeria, New York: Holmes \& Meier Publishers Inc., 161-192.

Ayeni, B. and Faniran, A. (1990) Geographical Perspectives on Nigeria's Development, Nigerian Geographical Associa-tion, University of Ibadan.

Barbour, G.M. (1990), Geography in Nigeria in B. Ayeni and A.

Bennett, R.J. (1985) Quantification and Relevance, in R. J. Johnston (ed.) The Future of Geography, New York \& London: Methuen.

Faniran, A. (1990) Concern for Geography, in B. Ayeni \& A.

Faniran (eds.) op cit., 306 - 326

Filani, M.O. (1985) Regional Planning in Nigeria: The Critical Issue of Economic Dependency, in J.O. Abiodun (ed.). Urban and Regional Planning Problems in Nigeria, Ife: University of Ife Press, 57 - 78.

Floyd, B.N. (1967) A Niche for Verbalizere in the New School, Nigerian Geographical Journal, 10(2), 133-36

Gana, J.A. (1985) The Political Economy of Regional Development: Some Implications for Regional Planning in Nigeria, in J.O. Abiodun (ed.) Urban and Regional Planning Problems in Nigeria, Ife: University of Ife Press, 35-56.

Hay, A.M. \& Smith R.H.J. (1967) Preliminary Estimates of Nigeria's Interregional Trade and Associated Money Flows, Nigerian Journal of Economic and Social Studies, Vol.8, 19-25. 
Jeje, L.K. (1990) Whither Geography, in B. Ayeni and A. Faniran (eds.) op cit., 290-303. Maboguun, A.L (1968) Urbanization in Nigeria: A Constraint on Economic Development" in Economic Development and Cultural Change, 13(4): 413 - 38.

Mabogunje, A.L. (1998) The History of the Department, in A. Areola \& S.I. Okafor (eds.), op cit., 1 - 18.

Ojo, A. (1980) Geography Today, Its Purpose Content and Method, in A. Faniran and P.O. Okunrotifa, eds. (1980) A Handbook of Geography Teaching, Ibadan: Heinemann Educational Books, 17 - 28.

Ojo,A.G.J. (1978) Thirty Years of Geographic Thought in Nigeria. Nigerian GeographicalJournal, Vol. 21, No. 1, 3 -23.

Ojo, G.J.A (1970) Some Observations on Journey to Work in Yorubaland, Economic Geography, 46(3), 459 - 71.

Okafor,S.I (1989) Research Trends in Nigerian Human Geography, The Professional Geographer, 41(2), 208 - 214.

Okafor, S.I. (1995) Third World Development and International Community, Ibadan Journal of the Social Sciences, Vol. 1, No.1,102-117.

Onokerhoraye, A.G. (1984) An Introduction to the History of Geographic Thought, Benin City: Department of Geography, University of Benin.

Oyebanji, J. O. (1984) Multiple Deprivation in Cities: The Case of Ilorin, Applied Geography, 4(1), 71 - 80.

Sada, P. (1987) Urban Households, Employment and Poverty in Nigerian Cities P.K. Makinwa and A. Ozo eds. in The Urban Poor in Nigeria, Ibadan: Evans Publishers.

Salau, A.T. (1986) Geography in Nigeria, The Professional Geographer, 41(2), 208214.

Salau, A.T. and Izeogu, I. (1986) Quality of Life Indications in Nigerian Cities, Paper Presented at the 29th Annual Conference of the Nigerian Geographical Association, ABU, Zaria. 